\title{
Study of protective cultivation of soil in Germany
}

\author{
V. Medvedev, \\ Academician of the National Academy of Sciences of Ukraine, Doctor of Biological Sciences \\ National Scientific Center "Institute of Soil Science and Agrochemistry named after O.N. \\ Sokolovsky »
}

The purpose. To study main ways of research works in protection of soils in Germany. Methods. Use of results of international project in study and spread of protective cultivation of soil in the world. Results. In Germany they use conservative, minimum and zero soil cultivation. Probes are carried out in long stationary experiments with the use of the wide program of concomitant observation with participation of leading experts of the country. Conclusions. The newest methods of soil cultivation have obvious soilprotective, economic and social effect. The acquired experience needs to be considered in analogous operations in Ukraine.

Key words: conservative, minimum, zero soil cultivation, Germany.

\section{Introduction}

In up-to-date Germany, the most widespread soil-cultivation methods are conservative and minimaltillage technologies, whereas the zero-tillage method is in somewhat lesser common use. Fundamental and applied research on soil protection tillage methods are conducted at Universities of Kiel, Goettingen, Bonn, Hessen, Kassel, Berlin, Osnabrueck, Muenchen, Hohenheim, Flensburg and others [1, 2]. Relevant scientific activities are funded from the State Budget through Federal Ministries of Food \& Agriculture, Environmental Protection, Education \& Science, and at the expense of Federal Land Funds as well. Non-governmental organizations, private institutions, individual investors and donors etc. are involved in financing of scientific activities also. Results collected across the Lands of western part of Germany are proceeded by Dr. F. Tebrugge, Dr. R.-A. Duhring and Dr. A. Michels (University of Hessen), and by Dr. M. Frielinghaus, Dr. L. Mueller et al. at R\&D Institute in Muechenberg in eastern Lands of Germany.

The following concepts of novel soil- cultivating technologies are now being adhered to in Germany:

The Conservative Soil-Tillage Agriculture involves definite technologies aimed at maximum possible safety-conservation of biodiversity, soil-composition and soil properties, along with protection against degradation-processes (soil-erosion, loss of humus, soil-overcompaction, etc.). Basic elements of this methodology are minimal soil-tillage intervention, and utilization of organic crop-residue mulch-matter. The conservative method is practiced on background of crop rotations prompted by adapted to natural and economic conditions, sufficient fertilizer inputs and, if necessary, anti-erosion and soil-reclamation efforts. This soil-conservative type is almost analoguous to the combined soil-treatment technologies being now in the most widespread use in Ukraine.

Minimal soil-tillage cultivation is a methodology of soil-treatment, intently limited in quantity of operations, depth of soil-layers and cultivated field-plots area. Basic, pre-planting and inter-row treatment operations are referred to as minimal soil-tillage methods. Inter-row cultivation performed either by combined tillage \& seeding machinery, or by chemical treatments, is also considered as the minimaltillage operation as well.

Among German soil-scholars and practitioners, the most often usable terms are "Winterfurche-, aussaat-, streifenweise-, zwischenreihen- Mini-Bearbeitung Technologien" (i.e., "The minimal winterfurrow-, seed-sowing-, row-, and inter-row soil-tillage technologies"). 
At first stage of introduction of minimal soil-cultivation method in Germany, conventional tools (such as cultivator- or disk- implements) were used, whereas traditional plough was meant to be abandoned forever.

Later on, the specialized (mainly combined) machine/implements became dominating in the farming practice. In recent years in EU-countries rather popular has become the term "strip-till" (or "row-till" in the USA), in the meaning of row-strip soil-tillage technology for growing many agro-crop varieties. In order to enhance the soil-water regime and accelerate the root-genesis proliferation in deeper soil-strata, the mini-treatment method is sometimes combined with in-depth soil-tillage procedures.

The zero cultivation method is a practice of cutting long-run furrows throughout the non-treated soilcover, of desired width and depth sufficient for subsurface sowing of crop-seeds. No other types of soiltreatment are needed there. Admitted is only a procedure of the sub-seed layer tillage in cases of soilovercompaction; yet such treatment is done with use of specialized implement, and hence, the natural vegetation soil-cover remains non-disturbed.

A compulsory requirement to the zero-tillage technology is preservation of permanent vegetation-soilcover formed of live plants and post-harvest mulch of stalk- and leaf- residues. In domain of zero-till technology, the major principle-motto sounds like: "Grain and produce - for man, crop-residues - for soil".

In Germany, the prevailing portion of the soil-surface are Cambisols (i.e., an approximate analogue of "Burozem podzolic soils" due to Ukrainian Soil-classification). German volcano-alkaline rocks are parents for Eutric Cambisols ("The mountain chip-stony burozems"), and the sandy areas are typical of Dystric Cambisols ("The sod-borozems in complex with slightly gleyed soils"). In more moisture-supplied areas, Stagnosols ("Gleyed soils") are widespread. The most fertile German earth is presented by dark-colored soils (i.e., Chernozems and Luvisols, being an approximate analogue of Ukrainian "Gray podzolized soils with a shallow humus profile"). Most of arable soils are degraded, whereby the especially widespread phenomena are caused by the water erosion.

Objective of the Study: to highlight main areas of this research in Germany aimed at substantiation of innovative soil- and resource-saving technologies, and specify good practices of German experience that could be introduced in adequate efforts at similar work in Ukraine.

Research methods. This article was written aground the materials from the International Project KASSA ("Knowledge Assessment and Sharing on Sustainable Agriculture") aimed at evaluation and dissemination of relevant knowledge $\left(^{*}\right)$.

(*) NOTE: Prof. V.V.Medvedev (author of this article) had also participated in the KASSA-Project as well.

Results and discussion. About the end XX century, five stationary field test-trials were carried out in Germany in order to research novel soil- protective activities under various soil-climatic conditions (Table1). Cereals, maize, rape, and sugar beet were cultivated in these experiments. Concomitant studies included monitoring of soil changes, plants' condition, economic indices, and observations for weeds and diseases (quite traditional for such the field work). The research process was participated by leading experts and soil-specialists from relevant institutions of Germany.

Pige-1 demonstrates definite agrotechnical features that cause influence by innovative technologies on energetic, economic and societal indices

1. General characteristics of Stationary Field Test- Trials on Conservative, Mini- and Zero- SoilTreatment Technologies in Germany

\begin{tabular}{|l|l|l|l|l|l|l|l|}
\hline \multirow{2}{*}{$\begin{array}{l}\text { Region } \\
\text { Germany }\end{array}$} & \multicolumn{2}{|l|}{$\begin{array}{l}\text { Granulometry } \\
\text { Composition, g/kg }\end{array}$} & Type of Soil & (a) & (b) & $\begin{array}{l}\text { Crop } \\
\text { Variables (years) }\end{array}$ \\
\cline { 2 - 8 } & Clay & Dust & Sand & & Rotation \\
\hline Hessen & 310 & 530 & 160 & $\begin{array}{l}\text { Eutric- } \\
\text { Fluvisol }\end{array}$ & 600 & 8 & $\begin{array}{l}\text { grain (8) } \\
\text { maize for silage (3) }\end{array}$ \\
\hline Wernborn & 265 & 559 & 176 & Stagnic & 625 & 7,6 & grain (14) \\
\hline
\end{tabular}




\begin{tabular}{|l|l|l|l|l|l|l|l|}
\hline & & & & Luvisol & & & rape (3) \\
\hline Ossenheim & 212 & 673 & 115 & $\begin{array}{l}\text { Luvic } \\
\text { Phaeozem }\end{array}$ & 575 & 9 & $\begin{array}{l}\text { grain (13) } \\
\text { sugar beet (4) }\end{array}$ \\
\hline $\begin{array}{l}\text { Hassen- } \\
\text { hausen }\end{array}$ & 138 & 667 & 195 & Luvisol & 630 & 8 & $\begin{array}{l}\text { grain (7) } \\
\text { rape (2) }\end{array}$ \\
\hline Bruechkuebel & 57 & 293 & 650 & $\begin{array}{l}\text { Eutric } \\
\text { Cambisol }\end{array}$ & 600 & 9 & $\begin{array}{l}\text { grain (8) } \\
\text { sweet maize (4) } \\
\text { sugar beet (5) }\end{array}$ \\
\hline
\end{tabular}

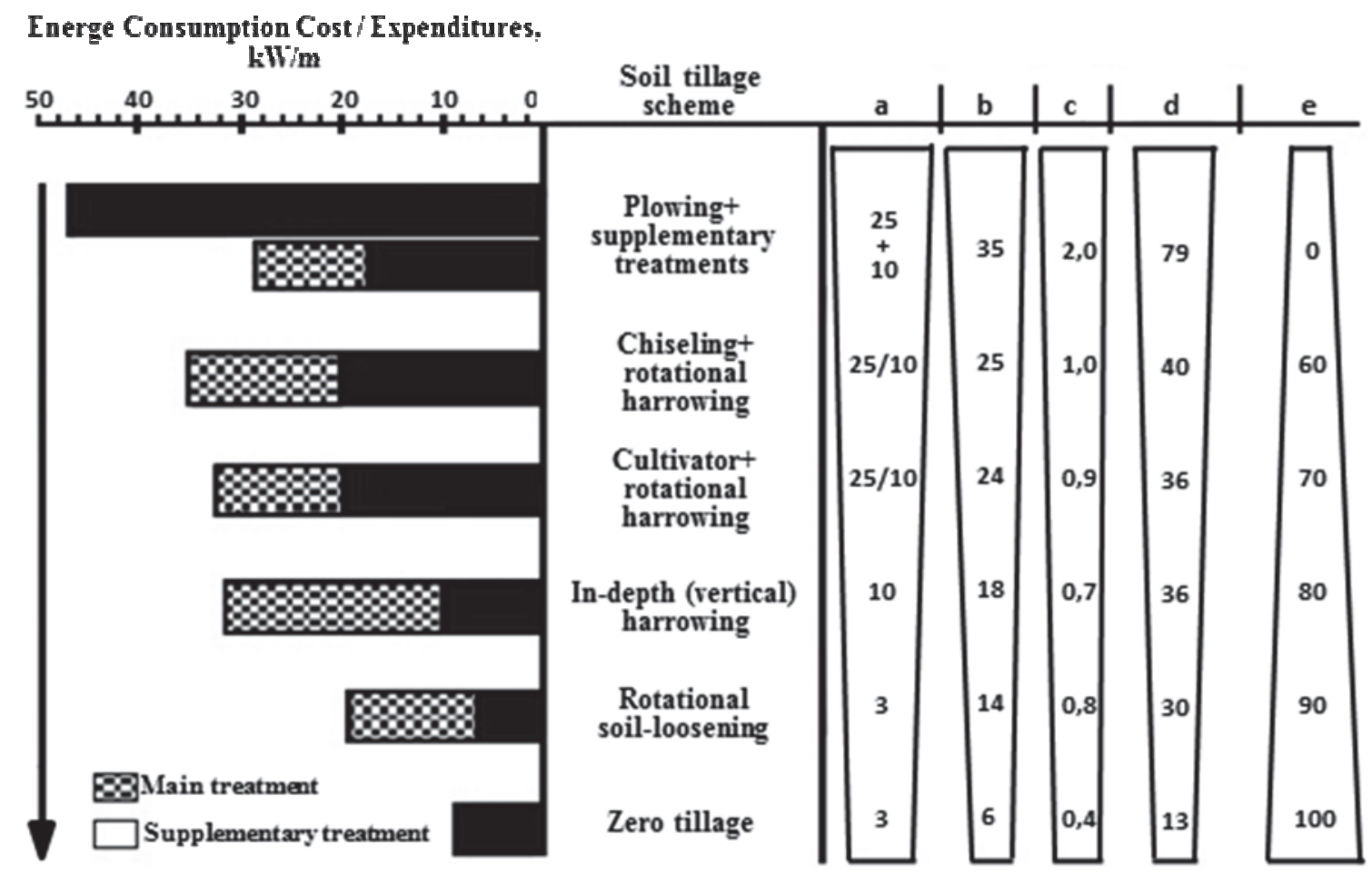

a - Depth of tillage, cm; b - Fuel consumption, liter/hour; $c$ - Time dedicated, hours/ha; $d$ - Degree of topsoil over-compaction, per cent; e - Amount of crop/vegetation post-harvest residues in 0 to 5-cm layer, per cent.

\section{Energetic, economic and societal characteristics of innovative soil cultivation technologies}

Since early years of zero cultivation- method introduction, agrarians noted that yield capacity of almost all crops was somewhat lower (or at previous level), as compared to that with traditional plowingtechnology. However with years (and owing to time- and fuel-savings, and lesser need for tools inventory), economic benefits of these new technologies became ever more evident, especially after several more seasons of field-operation. Compared to traditional methods, savings in zero-tillage costexpenditures amounted to about $€ 150$,- per hectare. Calculations of this effect during a 20 -year period show that perspective savings can reach $23 \%$.

The early years of zero- ("no-till") technology-application were marked with outbreak of weeds' thrive, that implied some surplus costs to acquire herbicides. However later on, the weeds' aggression had retreated significantly. During a $>20$-year period on the average, the cost of crop-protective means under new technology prevailed over the cost of conventional crop-protection technologies by only €20 - 30 per ha annually. Happily, rates of weediness and crop-diseases can be suppressed significantly via optimal choice of agro-culture species at follow-on crop- rotations. 
Technical aspects of successful implementation of soil-conservative technology depend on effective chopping and a uniform scatter of post-harvest residue-trash across the field. Similar requirements to zero-technology depend on high-quality procedures of planting crop-seeds, and accumulation of a rich amount of perennial vegetation and post-harvest stalk-leaf residues upon the field topsoil.

Agrarians have noted that it is the very 'no-till' technology that allows crop-seeds fall accurately in soil at planting through the narrow and long slots cut along the topsoil-cover by aid of disk-tools.

Currently in Germany, researchers are actively looking for agro-tools capable of: optimizing the seedplanting process, putting in the proper agro-chemicals, cultivating various crop species and providing an increased availability of crop-residue mulch-supplies to contribute to evergreen vegetation cover all over the agro-fields.

In Germany, issues of long-term impact of zero technology on biological indices (such as amount and activity of meso-and micro-flora, biodiversity and gas emissions) are studied rather actively. Particular attention is paid to the dynamics of humus behavior, because characteristic feature of zero-tillage technology is accumulation of organic matter on soil-surface and in the topsoil layer, which is a significant factor that can influence the biological activity of, and transformations in soil-compounds.

It was computed that with the zero-tillage method, every more $5 \mathrm{mg} / \mathrm{ha}$ of organic carbon and $1 \mathrm{mg} / \mathrm{ha}$ of total nitrogen are deposited in the topsoil-layer annually. Accumulation of organic matter in topsoil contributes to upgrade of soil-structure, soil-protection against erosion and herbicides' neutralization. Historically, the conventional plowing tillage made a dramatic metal-tool-intrusion into the soil-fauna and micro-flora media, because typically, these useful biodiversity-components inhabit prevailably the deeper soil-layers. To this end, a severe suppression of pathogenic and other soil-nematodes became possible with introduction of zero-tillage cultivation also.

Simultaneously, conditions for rain-worms' genesis were also changing positively under zero-tillage conditions. This beneficial process is naturally supported by a decent stock of organic matter within topsoil-layer, and availability of perennial network of micro-capillary channels throughout the soil strata, being altogether a sound moisture-accumulation media. One of thus revealed general laws declares that: "...As soon as mechanical treatment- intensity weakens away, the biodiversity activates its growth immediately". Regarding the emission of nitrogen-containing gases of various formulae, it should be noted that degree of nitrogen-losses depends on ratio of nitrification vs denitrification processes being regulated prevailably by actual air-water regime and current mode of soil-management. The zero-tillage technologies increase the $\mathrm{N}_{2} \mathrm{O}$ emissions, but reduce losses of $\mathrm{N}_{2}$ and the tabular $\mathrm{N}$-element. Concerning $\mathrm{CH}_{4}$ emission, its minimal losses were noted either from virgin soils, or on permanent agro-backgrounds under plow-cultivation. Last decade in Hessen, a research was conducted for in-depth- and modelstudies in this sphere.

No arguing, the zero tillage results somehow in soil-compaction of upper part of the root-bearing layer, but leaves the surfacial ( $0-3 \mathrm{~cm}$-thick) layer quite intact. At least, structural density of sub-arable soillayer being permanently plough-disturbed, is significantly greater than soil-density at the same depth after no-till treatment (i.e., $1.51 \mathrm{vs} 1.41 \mathrm{t} / \mathrm{m}^{3}$, respectively). These comparative numerical data are especially convincible at soil-density measurements.

The total amount and size of micro-soil-capillaries tend to decrease proportionally to elimination of soil-loosening operations. The zero tillage creates an artificial micro-soil capillary-environment within the root-bearing layer, whose ( $50 \%)$ bulk contains plenty of $>120 \mathrm{mcm}$ macro-pores. However, these porous capillaries are physically not very durable and hence, they undergo ruining in winter-period. At the same time, the state of tiny $(<10 \mathrm{mcm})$ capillaries remains relatively stable even after frosty winter-seasons. Judging by these facts, one may assume that the non-treated soils possess higher water capacity (owing to significant amount of micro-soil-capillaries), thus exceeding the total amount of mobile moisture under zero-technology conditions. That is why the non-treated soils need longer time to get warmed up during spring-season, where processes of organic matter-mineralization and nitrogen-accumulation are inhibited.

The best performance options of zero-tillage technology were shown by the wheel-borne field-traction machinery even under excessive soil- moisture conditions. The less often the field-traction vehicles roam 
across the agro-field, the less compacted is the soil, with almost no soil-crust nor soil-runoff. These facts had been confirmed in stationary field test-trials and by numerous model experiments. At traditional soilplowing practice, amount of solid fraction-runoff made up to $6.400 \mathrm{~kg} / \mathrm{ha}$ soil a year, while at zero tillage, only $900 \mathrm{~kg} / \mathrm{ha}$.

The soil- runoff- resistance effect is a very important factor in concern of dusty erosion- prone soils. Impact of various tillage technologies on chemical properties of soils is reportedly associated with effect of post-harvest crop-residues' mineralization and soils' contamination with organic stuff and inorganic matter. It is believed that plowing intensifies the mineralization process (due to easier availability of $\mathrm{O}_{2}$, whereby the zero-tillage is able to equi-balance the mineralization intensities. Losses of phosphates and nitrates at zero technologies may increase due to preferential moisture-flows (during heavy rain seasons) through abundance of relatively wide permanent capillary-channels. Recent findings have proven a fact that at zero technologies, the contamination pollutants (as inherent components of mineral fertilizers) do not interact with solid phase of soils and hence, penetrate throughout the sub-arable soil-stratum. Moreover, the upper stratum of topsoil undergoes contamination as well - due to elevated sorption capability of soil-cover enriched with post-harvest crop-residues and humus. The increased pollution of the topsoil layer, inflicted by zero tillage technologies, has been proven experimentally.

Data on the influence of zero-tillage technology on changes in soil-ecological indices (collected by $\mathrm{F}$. Tebrugge et al. [3-7]) were derived from results of five stationary field test-trials over 20 years of research in Germany (Table-2).

\section{Comparison between soil-ecological indices of zero-tillage versus those of traditional plowing} technologies

\begin{tabular}{|c|c|c|}
\hline \multirow{2}{*}{ Soil-ecological indices } & Below & Above \\
\hline & \multicolumn{2}{|c|}{ traditional tillage indices, $\%$} \\
\hline Summarized area of wheel-tracks, $\%$ /ha & 54,5 & \\
\hline Mechanical loading on site-soil (ton-km /ha) & 69,2 & \\
\hline Soil -loading during triaxial-vehicle performance-test & & 200 \\
\hline $\begin{array}{l}\text { Depth of wheel-tracks }(\mathrm{cm}) \text {, at testing the } 34.3 \mathrm{kN} \text {-powered agro-field- } \\
\text { vehicles }\end{array}$ & 87 & \\
\hline Soil-structural density $\left(\mathrm{mg} / \mathrm{m}^{3}\right)$ of: & & \\
\hline 0 to $25-\mathrm{cm}$-thick layer; & & 20 \\
\hline 25 to $35-\mathrm{cm}$-thick layer & 7 & \\
\hline Quantity of of scarabeoid larvae in soil $\left(\mathrm{pcs} / \mathrm{m}^{2}\right)$ & & 700 \\
\hline $\begin{array}{l}\text { Quantity of of larvae channels per }\left(1 \mathrm{~m}^{2}\right) \text { soil-plot, within } 25-\mathrm{cm} \text { and } 45- \\
\mathrm{cm} \text { - deep layers }\end{array}$ & & 570 \\
\hline Micro-faunal activity in 0-25-cm- layer & & 34,2 \\
\hline Durability of soil-aggregates under rain-simulator impact & & $(b)^{*}$ \\
\hline Rate of moisture penetration during vegetation season ( $\mathrm{cm} /$ day) & & $(b)^{*}$ \\
\hline Soil-sagging under loading, ton /ha & 90 & \\
\hline Moisture-water runoff $(\mathrm{mm})$ & 69 & \\
\hline Horisontal replacement ( $\mathrm{kg} / \mathrm{ha})$ of: & & \\
\hline herbicides & 70 & \\
\hline nitrates & 85 & \\
\hline water-soluble phosphates & 65 & \\
\hline Nitrates' alkalinization $\left(\mathrm{NO}_{3} \rightarrow \mathrm{N}, \mathrm{mg}\right)$ & $(a)^{*}$ & \\
\hline $\mathrm{CO}_{2}$ emission from fuel combustion ( $\mathrm{kg} / \mathrm{ha}$ ) & 84,9 & \\
\hline $\mathrm{CO}_{2}$ emission from soil carbon oxidation $\left(\mathrm{gCO}_{2} / \mathrm{m}^{2}\right)$ & $(b)^{*}$ & \\
\hline $\begin{array}{l}\text { Organic matter content in } 0-30 \mathrm{~cm} \text { soil- layer: } \\
\text { ton /ha }\end{array}$ & & 8,4 \\
\hline
\end{tabular}




\begin{tabular}{|c|c|}
\hline $\begin{array}{l}\mathrm{t} / \mathrm{ha} / \mathrm{g} / 100 \mathrm{~g} \text { soil } \\
\text { Availability of field snakes and mice populations }\end{array}$ & $\begin{array}{l}22 \\
(\mathrm{a})^{*}\end{array}$ \\
\hline $\begin{array}{l}\left({ }^{*}\right) \text { NOTES: } \\
(a)^{*}: \text { an evident difference } \\
(b)^{*}: \text { a very expressive difference }\end{array}$ & \\
\hline
\end{tabular}

No less interesting is a generalization of zero soil-tillage effectiveness parameter, carried out per economic and societal indices by the above-named German researchers, and derived from results of 20 years- lasting experience (Table 3 ).

\section{Economic and societal indices of zero-till technology compared to traditional plowing method}

\begin{tabular}{|c|c|c|}
\hline \multirow{2}{*}{ Economic and societal indices } & Below & Above \\
\hline & \multicolumn{2}{|l|}{$\begin{array}{l}\text { traditional } \\
\text { indices, } \%\end{array}$} \\
\hline Equipment cost/expenditures (Euro) & 38,7 & \\
\hline Cost of tractor operation/maintenance (Euro/ha) & 85,8 & \\
\hline Engine-power required $(\mathrm{kW} / \mathrm{m})$ & 75 & \\
\hline Cost of an hour of operation (hr/ha) & 79,7 & \\
\hline Cost of motor-fuel and motor-oil (I/ha) & 85 & \\
\hline Field-operator's salary (Euro/ha) & 79,4 & \\
\hline Cost of repair (Euro) & 65 & \\
\hline Cost of herbicides (Euro/ha) at crop rotations with $75 \%$ & & 15 \\
\hline content of grain/cereal Cost of overall cultivation: & 100 & \\
\hline Plowing \& sowing & 27,3 & \\
\hline Work productivity rate (ha/hour) & & 390 \\
\hline Summarized length of field-vehicles' runs $(\mathrm{km} / \mathrm{ha})$ & 67,2 & \\
\hline Average yielding capacity of: & & \\
\hline winter wheat & 0 & 0 \\
\hline winter rye & & 4 \\
\hline winter barley & 0 & 0 \\
\hline oat & 8 & \\
\hline winter rape & & 9 \\
\hline sugar beet & & 2 \\
\hline sweet maize for silage & 9 & \\
\hline $\begin{array}{l}\text { Economic profitability (Euro/ha) derived (in different crop-rotations) from } \\
\text { average results of } 17 \text { years' experience gained upon five test-soil-plots }\end{array}$ & & $7-20$ \\
\hline
\end{tabular}

Using the data from long-term field test-trials in Germany, the following direct and indirect economic and organizational advantages of innovative soil-conservation technologies (as compared to traditional plowing methods) have been confirmed [8-10]:

limitation and control of energy- and fuel- consumption;

reduction of sowing time and limitation of investment expenditures;

limitation and control of distance run by agri-machinery per 1 ha with limitation and control of wheeltracks and rates of technogenic loading on soil;

enhancement of soil/track-passability conditions and soil-resistance to loading.

However, estimation of energetic and economic efficiencies via simple comparison between traditional methods and zero- technologies is not enough to manifest an absolute efficiency of no-till soiltreatment. 
The efficiency of innovative soil-protective agro-technologies implies a much broader outlook, since "no-till" methods avoid active soil-destruction; rectifies profound soil-formation phenomena and bring their beneficial effect into ecological environment.

It should be noted that typically, a present-day land-user is inclined to safequard his plowing tools in reserve, arguing for his strategy in view of its somewhat elevated yielding capacity.

However, even with some increase in yield actually gained with the plough, justifying the outdated plowing traditions today is still a very erroneous policy.

Having once chosen our way towards ecological farming prosperity, we are committed to adhere to it without hesitation.

After all, the major idea of this recourse is not solely the harvest-yield index in itself, in view of soil protection-care which is also no a less important deal. To say more in addition, a somewhat elevated post-plowing yield-effect, as a rule, is comparatively not so rich as imagined.

However, this beneficial idea (that promises a positive influence on status of ecological environment) can hardly overcome an average farmer's vision, nor incline his mind in favor of introducing zerotechnologies in present-day soil-treatment policies.

To an average farmer, the productivit- yield- factor is still of the most importance.

That is why the progress of zero-till technologies of soil-cultivation in Germany is rather slow so far.

Now, let's cast a glance at relevant research work on soil-conservative, mini- and zero-tillage methodologies by leading profile institutions in Germany.

Thus, at University of Hessen, aspects of dynamics of microorganisms' activity in soil under different treatment regimes; impact by different cultivation systems on transformation of organic carbon in municipal waste; technical and soil- protection factors during the [rape-sowing through maize-harvesting] season; impact of soil-treatment on methane-oxidation process; methane-migration within the soil-profile; accumulation of polychlorinated biphenyls in artificially treated soils etc, are researched.

University of Paderborn, Technical University in Muenchen and Institute of Plant Science \& Soil Science in Mecklenburg are partly engaged in assessment of innovative systems' effectiveness at growing rape and leguminous plants in crop rotations.

Technical University of Braunschweig is partly engaged to investigate deceases of haricot- bean and lupine-crops in mulched soils.

University of Trier is partly engaged in examining an impact of innovative techniques on behavior of rain-worm popoulations.

University of Kiel is engaged in studies for: effects of various treatments regimes on physical, mechanical and rheological properties of unsaturated powdery Luvisol; mechanical properties of overcompacted gleyed soils (being loosened with relevant tools); inter-relation between issues of zerotillage and soil structure recovery.

The Sugar Beet Institute and University of Goettingen (in Lower Saxonia) are partly engaged in summarization of comparative effects of plowing and innovative cultivation methods collected during 20 years of 'no-till' application.

University of Hohenheim is engaged in studies for environmental aspects of differentiated soil cultivation; optimization of zero tillage at maize- cultivation; soil-fertilization under zero treatment regimes; technologies of planting vegetables in mulched soils.

The Leibniz Center and the R\&D Institute for Agricultural Landscapes \& Land Use are partly engaged in studies for long-term conservative cultivation influence on rhizosphere microorganisms; and feasibilities of conservative cultivation on sandy soils.

Center for Environment \& Health, Swiss Center for Agroecology \& Agriculture, and Technical University in Muenchen are partly engaged in studies for quality of organic soil-matter under different soilcultivation conditions.

Private investors contribute as well by financing the studies for technologies of sowing crop-plants into straw-mulched soils under zero- tillage regimes. 


\section{Conclusions}

Germany, numerous stationary long-term field test-trials of soil-conservative, mini- and zero- soiltreatment are actively conducted. The relevant research work, supported by various observations on economic, environmental and societal aspects, have proven the benefits of innovative technologies that provide a novel basis for their active introduction into Agro-industry.

In Ukraine, similar studies should be intensified as well, taking into account Germany's experience, especially with regard to the variety of relevant efforts in observations, which significantly increase the informative message of this work.

\section{Bibliography}

1. During R.-A. Conservation Agriculture, Organic Farming and GM crops in Germany/R.-A. During, A. Michels//Main focus: Western Germany. Report D 1.1. A 5. KASSA Project. CIRAD. France. - 2006. - P. $1-45$.

2. Conservation Agriculture, Organic Farming and GM crops in Germany/M. Frielinghaus, L. Muller, M. Willms, U. Andreas//Main focus: Eastern Germany. Report D 1.1. A 6. KASSA Project. CIRAD. France. 2006. - P. 1-16.

3. Tegrügge $F$. Comparison of intensive machine tillage and non-plow soil treatment /F. Tebrügge, A. Wagner //Int. Conf. on self-healing agriculture on basis of no-till system approach. Dnipropetrovsk 2004 97-104 pps.

4. Tegrügge $F$. Crop yields and economic aspects of no-tillage compared to plough tillage: Results of long-term field field test-trials in Germany/F. Tebrügge, A. Bohmsen//Proceedings of the $2^{\text {nd }}$ Activitieshop 15-17 May, Silsoe, UK: Experience with the applicability of no-tillage crop production in the WestEuropean countries. Wissenschaftl. Fachverlag Gieben. - 1997. - P. 25-44.

5. Tegrügge F. Results and conclusions of the surveys on No-Tillage//F. Tebrügge, France: Experience with the applicability of no-tillage crop production in the West-European countries. Wissenschaftl. Fachverlag Gieben. - 1997. - S. 54-153.

6. Tegrügge $F$. Reducing tillage intensity- a review of results from long-term study in Germany/F. Tebrügge, R.-A. Durring//Soil Tillage Research. - 1999. - 53. - S. 15-28.

7. Tegrügge $F$. Comparison of soil machine interactions by intensive tillage and notillage $22 \mathrm{pp} . / \mathrm{F}$. Tebrügge //Proceedings $4^{\text {th }}$ Inten. Conf. on Dynamics, CD-ROM. -2000 . Adelaide, Australia.

8. Geophysical Methods for imaging Soil Compaction and Variability of Soil Texture on Farm Land/H. Petersen, H. Fleige, W Rabbel, R. Horm//Advances in Geoecology 38 "Soil Managing for Sustainability", Catena Verlag GMBH,35447, Reiskirchen, Germany. 2006. - P. 261-272.

9. Neubauer W. Research Report: Acker- und pflanzenbauliche Maßnahmen zum Bodenschutz in Mecklenburg-Vorpommern und Möglichkeiten zu ihrer praktischen Umsetzung/W. Neubauer. - 2003).

10. Durring R.-A. Depth distribution and accumulation behavior of pollutants in long-term differently tilled soils/R.-A. Durring, T. Hob, S. Gath//Soil Till. Res. - 2002. P. 183-195. 